\title{
Mračna strana slobode kretanja: kada su u koliziji interesi pojedinca i društva ${ }^{1}$
}

DOI: https://doi.org/10.11567/met.35.1.4 UDK: 331.556.43:364(4)

$172: 331.556 .43(4)$

Izvorni znanstveni rad Primljeno: 04.12.2019. Prihvaćeno: 13.12.2019.

\author{
Iris Goldner Lang
}

Pravni fakultet, Sveučilište u Zagrebu, Zagreb

igoldner@pravo.hr

Maroje Lang

Hrvatska narodna banka, Zagreb

maroje.lang@hnb.hr

\begin{abstract}
SAŽETAK
Pravo na slobodu kretanja jedno je od najpozitivnijih postignuća europske integracije. Ovaj rad želi upozoriti na kontradiktorne učinke tog prava, posebice u novim državama članica Srednje i Istočne Europe, uključujući i Hrvatsku. Pravo na slobodu kretanja radnika stvara brojne pogodnosti za radnike migrante i za EU u cjelini jer omogućuje slobodno kretanje radnika iz područja s visokom nezaposlenošću u područja u kojima postoji potražnja za radnicima. No ne treba podcijeniti socijalne, ekonomske i političke učinke tog prava na države članice iz kojih radnici odlaze. Cilj je ovog rada istražiti što je do sada učinjeno i koje nove mjere na europskoj razini treba uvesti kako bi se ublažili negativni učinci te slobode. Autori obrazlažu da rješenje nije u ograničenju slobode kretanja, već - upravo suprotno - u viziji snažnije europske integracije koja bi imala za cilj smanjenje razlika olakšavanjem razvoja regija koja zaostaju. U tom se kontekstu tekst osvrće na korištenje postojećih i mogućnost uvođenja novih EU fondova, na mogućnost rekonceptualizacije pojma građanstva Unije i upućuje na potrebu potpune primjene Europskog stupa socijalnih prava. Rad se sastoji od četiri dijela. Nakon uvodnog poglavlja, u drugom se dijelu opisuju nedavni trendovi te pokretači i učinci mobilnosti unutar EU-a. Treći dio istražuje koje su mjere do sada korištene kako bi se umanjili negativni učinci slobode kretanja radnika. Zaključno poglavlje iznosi prijedloge novih politika te objašnjava zašto bi kombinacija nacionalnih i europskih mjera bila optimalna.
\end{abstract}

KLJUČNE RIJEČI: sloboda kretanja radnika, negativni učinci, fondovi EU-a, građanstvo Unije, Europski stup socijalnih prava

1 Ovaj rad je prijevod originalnog članka napisanog na engleskom jeziku autora Iris Goldner Lang i Maroja Langa pod nazivom „The Dark Side of Free Movement: When Individual and Social Interests Clash" koji će 2020. godine biti objavljen u izdanju Brill-a u knjizi pod nazivom EU citizenship and Free Movement: Taking Supranational Citizenship Seriously (urednici: S. Mantu, P. Minderhoud i E. Guild) i za čiji su prijevod i objavljivanje na hrvatskom jeziku svoju suglasnost dali izdavač (Brill) i urednici knjige.

Stavovi izneseni u ovom radu su stavovi autora i ne odražavaju nužno stavove institucija u kojima su zaposleni. 


\section{UVOD}

Pravo na slobodu kretanja jedno je od najpozitivnijih postignuća europske integracije. Pravo na slobodno kretanje radnika stvara brojne pogodnosti ne samo za radnike migrante (iseljenike) već $\mathrm{i}$ za države članice primateljice $\mathrm{u}$ koje radnici dolaze te za Europsku uniju (EU) u cjelini, jer omogućuje slobodno kretanje radnika iz područja s visokom nezaposlenošću u područja u kojima postoji potražnja za radnicima. No ne treba podcijeniti socijalne, ekonomske i političke učinke tog prava na države članice iz kojih radnici dolaze (države članice podrijetla) - posebno za manje razvijene regije - jer sloboda kretanja narušava njihovu proizvodnju i poreznu bazu te povećava razlike između više i manje razvijenih država članica i regija u EU-u.

Cilj je ovog rada opisati ovaj problem koji se očituje u suprotnim interesima Europske unije u cjelini, država primateljica i pojedinaca koji ostvaruju pravo na slobodu kretanja, s jedne strane, te interesa država članica podrijetla, s druge strane, uključujući i slabije razvijene regije. Iako prepoznaju taj problem, autori polaze od pretpostavke da je sloboda kretanja važno i pozitivno postignuće europske integracije, čiji se nedostaci ne smiju iskoristiti u svrhu ograničavanja prava na slobodu kretanja radnika. Upravo suprotno, rješenje nije u ograničenju tog prava, već u viziji snažnije europske integracije čiji bi cilj bio smanjenje razlika olakšavanjem razvoja regija koje zaostaju.

Rad se sastoji od četiri dijela. Drugi dio opisuje nedavne trendove, kao i pokretače i učinke mobilnosti unutar EU-a. Treći dio istražuje koje su inicijative, studije i mjere do sada bile upotrijebljene - na razini EU-a i na nacionalnoj razini - kako bi se umanjili negativni učinci slobode kretanja radnika. Zaključno poglavlje objašnjava zašto bi kombinacija nacionalnih i europskih mjera bila optimalna za rješavanje negativnih učinaka slobodnoga kretanja radnika. Također se iznose prijedlozi politika koje bi se mogle upotrijebiti u budućnosti, kao što su rekonceptualizacija građanstva Unije i potpuna primjena Europskog stupa socijalnih prava (ESSP) te uvođenje novih financijskih mjera i instrumenata na razini EU-a koji bi mogli ublažiti negativne učinke slobodnoga kretanja radnika, bez ograničenja te temeljne slobode.

\section{KRETANJE RADNIKA UNUTAR EUROPSKE UNIJE: TRENDOVI, UZROCI I POSLJEDICE}

Slobodno kretanje radnika ima brojne prednosti. Osim što osigurava bolju raspodjelu radnika na cijelom kontinentu, kretanje radnika pridonosi jačoj europskoj integraciji. Ono promiče međukulturni dijalog kroz susret i upo- 
znavanje osoba različitih narodnosti, jačajući europski identitet. Usto, kretanje radnika važan je mehanizam za rješavanje učinaka asimetričnih šokova unutar monetarne unije. Stoga se povećanje mobilnosti radnika potiče kao pozitivan trend za EU.

Da bismo razumjeli kritiku slobode kretanja radnika, važno je analizirati nedavne trendove. Kako se mobilnost unutar EU-a povećala tijekom posljednjeg desetljeća, posebno pogađajući neke regije, u nekim su se državama članicama pojavili distributivni i negativni učinci, koji su se počeli javljati u društvenim i političkim raspravama. Za razumijevanje promjene pogleda na slobodu kretanja radnika i rješenje negativnih učinaka te slobode treba razumjeti što utječe na migracijske trendove te analizirati posljedice koje oni imaju na različitim razinama. Ispravna dijagnoza i razumijevanje stanja nužni su kako bi se moglo analizirati dosad isprobane politike i one politike koje bi trebalo aktivirati za učinkovito rješenje ovog problema. Ovo poglavlje opisuje trenutačno stanje kroz prikaz osnovnih statističkih podataka, razmatra uzroke mobilnosti unutar EU-a i na kraju raspravlja o pozitivnim i negativnim učincima kretanja radnika. Poseban naglasak stavljen je na utjecaj kretanja radnika za pojedince, za EU u cjelini, kao i za države članice iz kojih radnici odlaze i u koje se useljavaju.

\subsection{Nedavni trendovi kretanja radnika unutar EU-a}

Posljednjih godina povećana je mobilnost radnika u EU-u. Prema podacima Eurostata (2019), broj radno sposobnih građana EU-a (20 - 64) koji borave u drugoj državi članici povećao se s 2,7\% u 2008. godini na 3,9\% u 2018 (slika 1). Taj trend prati sličan porast koji je ostvaren u prethodnom desetljeću, a koji je obilježilo pristupanje novih država članica EU-u. ${ }^{2}$

Nedavno povećanje mobilnosti unutar EU-a odvijalo se kroz dva glavna migracijska kanala (Alcidi i Gros, 2019). Prvi i najvažniji jest onaj iz siromašnijih država članica Srednje i Istočne Europe, koji se intenzivirao nakon njihova pristupanja Europskoj uniji i prestankom prijelaznog razdoblja $\mathrm{u}$ kojemu je sloboda kretanja radnika bila ograničena. ${ }^{3}$ Stečeno pravo na slobodno kretanje omogućilo je državljanima novih država članica da iskoriste mogućnost zaposlenja u bogatijim i razvijenijim dijelovima EU-a. Drugi

2 Broj mobilnih građana EU-a povećan je za oko četiri milijuna ili nešto više od $1 \%$ stanovništva u svakom od posljednja dva desetljeća.

3 Draženović, Kunovac i Pripužić (2018) procjenjuju da su pristupanje i ukidanje prijelaznih odredbi povećali iseljavanje iz novih država članica (države podrijetla) u središnje države EU-a (države primateljice) za $40 \%$. 
je migracijski kanal od europskog juga prema sjeveru. Taj smjer kretanja radnika već je dugo prisutan. On se povećao tijekom i nakon globalne financijske krize i europske dužničke krize, koje su posebno pogodile neke države članice (Grčku i Portugal) te usporile rast i povećale nezaposlenost u većini južnih država članica. Taj se proces odvijao paralelno s porastom potražnje za radnicima u nekim bogatijim državama članicama, posebno u Njemačkoj, što je pojačalo tradicionalno kretanje radnika s europskog juga prema sjeveru. Mobilnost visokoobrazovanih građana unutar EU-a, koji traže najbolje poslove na zajedničkom tržištu - kao treći migracijski kanal nije znatnije pridonijela nedavnom porastu broja stranih radnika.

Prema podacima Eurostata, u 2018. godini bilo je 12,9 milijuna radnika migranata iz EU-a. Većina stranih radnika dolazi iz velikih istočnih ili južnih država članica: Rumunjske (2,5 milijuna), Poljske (1,8 milijuna), Italije (1,3 milijuna) i Portugala (1 milijun). No države koje su najviše pogođene iseljavanjem, mjereno udjelom iseljenih građana u odnosu na ukupno stanovništvo, bile su najsiromašnije države članice: Rumunjska (21,3\%), Hrvatska $(15,0 \%)$, Litva (14,5\%), Portugal (13,6\%), Bugarska (13,3\%) i Latvija (11,8\%). Istodobno, velike, stare i prosperitetne države članice nisu imale mnogo odljeva. U 2018. samo je 1,0\% radno sposobnih Nijemaca i 1,1\% Britanaca živjelo u drugim državama članicama.

Iako države članice podrijetla imaju dugu tradiciju iseljavanja, velik udio njihovih mobilnih radnika nastao je nedavno. Tijekom posljednjeg desetljeća udio rumunjskih mobilnih građana porastao je za 11,8 postotna boda (u daljnjem tekstu: pb), Litavaca za 7,9 pb, Latvijaca za 7,8 pb, a Bugara za 7,7 $\mathrm{pb}$. Novostečeno pravo slobode kretanja iskoristili su mnogi pojedinci koji su se odlučili preseliti u druge, prosperitetnije države članice u potrazi za poslom ili boljim radnim i životnim uvjetima. Kao rezultat, udio mobilnih državljana povećao se u svim novim državama članicama tijekom posljednjeg desetljeća, iako je taj broj još uvijek malen u slučaju Češke i Slovenije. No čini se da se ovaj trend usporio u mnogim novim državama članicama zbog povećanja prosperiteta i mogućnosti zapošljavanja, a i broj potencijalnih migranata smanjio se s obzirom na to da je većina zainteresiranih za preseljenje već otišla. Slijedom toga većina novih država članica doživjela je vrh iseljavanja, a neke su počele bilježiti povratak svojih državljana (Poljska). Tri države koje i dalje bilježe značajan odljev stanovništva jesu najmlađe i najsiromašnije države članice: Rumunjska, Hrvatska i Bugarska.

Grčka i Portugal, dvije države članice koje su bile najteže pogođene nedavnom ekonomskom krizom, također su imale značajan odljev radnika zbog 
velike nezaposlenosti. Italija i Španjolska, koje su također pogođene nedavnim gospodarskim događajima, doživjele su relativno male odljeve. One su istodobno popularno odredište frankofonih Rumunja zbog jezičnih sličnosti. Najpopularnija odredišta za radnike jesu bogate stare države članice $s$ velikom potrebom za stranim radnicima. U početku je najdraža destinacija bila Velika Britanija, koja nije uvela prijelazno razdoblje za slobodu kretanja radnika, a koju je poslije nadmašila Njemačka.

Slika 1. Mobilni građani EU-a radne dobi $(20$ - 64) prema državi državljanstva, postotak njihova prebivališta u zemlji

Figure 1. EU mobile citizens of working age (20-64) by country of citizenship, $\%$ of their home-country resident population

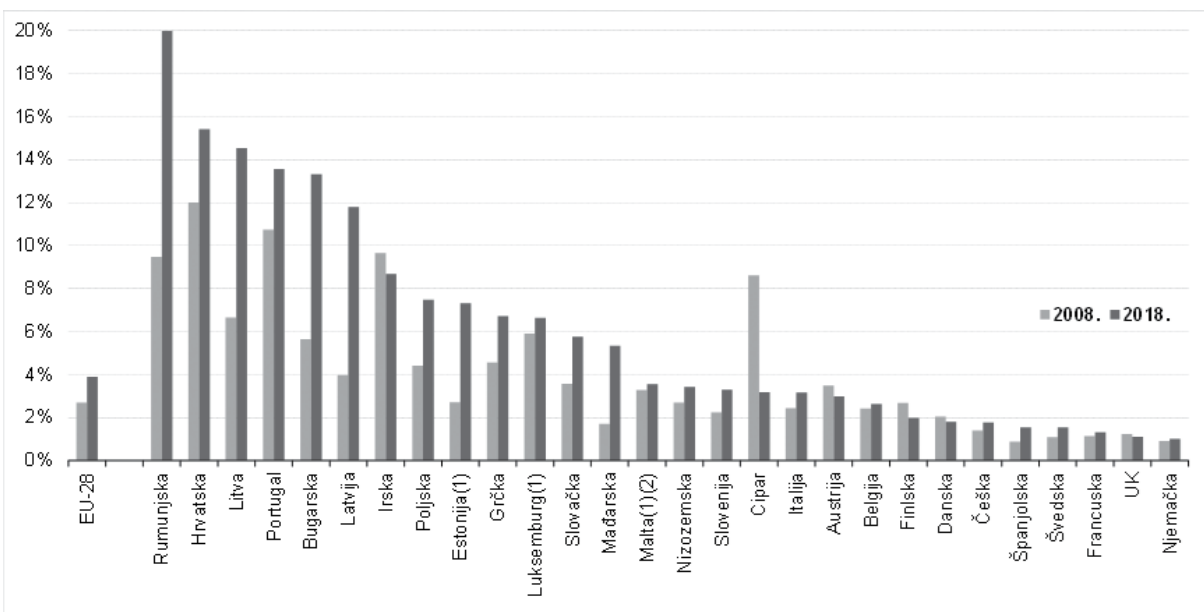

(1) Podaci niske pouzdanosti za 2008.; (²) Podaci niske pouzdanosti za 2018.

Izvor: Eurostat (2019). EU citizens living in another Member State - statistical overview, Statistics Explained.

\subsection{Uzroci mobilnosti unutar Europske unije}

Literatura o migracijama razloge preseljenja za radnike objašnjava potisnim čimbenicima (push factors) i privlačnim čimbenicima (pull factors). Potisni čimbenici povezani su sa stanjem $u$ državi podrijetla koje potiče njene građane na iseljavanje. Oni uključuju stanje fizičke opasnosti - poput političkoga ili vjerskog progona, ratova i prirodnih katastrofa - kao i ekonomske okolnosti zbog kojih pojedinci ne mogu ostvariti željeni životni standard zbog stanja na tržištu rada, što rezultira niskim plaćama i nestašicom rad- 
nih mjesta. S druge strane, privlačni čimbenici odnose se na atraktivnost države primateljice. Privlačni čimbenici određuju bi li preseljenjem u novu državu pojedinci ostvarili pogodnosti koje nisu imali u matičnoj državi.

Ponekad neki čimbenici istovremeno imaju potisne i privlačne karakteristike. To se odnosi na stanje na tržištu rada, posebno na razlike u plaćama i mogućnostima zaposlenja, kao i na zadovoljstvo životom, koje je povezano sa životnim standardom, mjereno kvalitetom privatne i javne potrošnje te dostupnosti javnih usluga. Osim toga na osobni izbor mogu utjecati i drugi životni aspekti koji nisu izravno povezani sa životnim standardom, poput društvene i političke klime te korupcije. ${ }^{4}$

Razlike u plaćama među državama u velikoj mjeri utječu na migracije kvalificiranih i nekvalificiranih radnika. No preseljenje povlači za sobom niz troškova i rizika. Financijski troškovi preseljenja mogu se pokriti većim prihodima, no postoje i druge administrativne prepreke i rizici povezani s integracijom u novu sredinu. Proširenje Europske unije i uklanjanje prepreka slobodi kretanja radnika unutar EU-a potaknuli su mnoge osobe iz siromašnih država članica da iskoriste priliku i potraže veće plaće u bogatijim državama članicama. To je bilo posebno izraženo u državama s dugom povijesti iseljavanja, gdje mreža ranijih iseljenika olakšava daljnje iseljavanje. Na temelju novijih podataka Alcidi i Gross (2019) sugeriraju da se iseljavanje iz novih država članica smanjuje kad lokalne realne neto plaće ${ }^{5}$ dosegnu $60 \%$ plaća u državama primateljicama. Slijedom toga proces konvergencije, posebno u području plaća, usporava iseljavanje. Osim povećanja produktivnosti na brži rast plaća u državama članicama iz kojih se stanovništvo iseljava utječu povećanje potražnje za radnicima i nedostatak radne snage zbog iseljavanja. Veza između razine plaća i iseljavanja potvrđena je nedavnim kretanjima u određenim državama, posebno u Poljskoj, u koju su se počeli vraćati iseljeni radnici (Chaffin, 2017).

Razlika u stopi nezaposlenosti još je jedan čimbenik koji istovremeno tjera $\mathrm{i}$ privlači radnike na iseljenje. $S$ jedne strane, visoka razina nezaposlenosti $u$ državama podrijetla može potaknuti nezaposlene koji se ne mogu zaposliti u državi podrijetla da posao potraže u inozemstvu. Taj je čimbenik posebno važan za mlađe i slabije zaposlene skupine. Obrazovaniji radnici uglavnom lakše pronalaze posao, što umanjuje šanse za neobrazovane. Za razliku od kretanja radnika između zapadnih, bogatijih država članica - kamo obično

4 Za nalaze o važnosti nezadovoljstva iseljenika socijalnom i političkom situacijom, kao najčešćim razlogom iseljavanja iz Hrvatske, vidi poglavlje 2.2.

5 Neto plaće (bruto plaće umanjene za porez i doprinose), prilagođene kupovnoj moći. 
najobrazovaniji migriraju u potrazi za najboljim radnim mogućnostima - ili useljavanja radnika iz trećih zemalja, gdje su za mogućnost preseljenja potrebne posebne radne vještine ili financijska sredstva, uklanjanje prepreka slobodnom kretanju radnika iz novih država članica omogućilo je preseljenje mnogih nekvalificiranih i nezaposlenih osoba iz novih država članica i država članica najviše pogođenih europskom dužničkom krizom.

$S$ druge strane, brojnim bogatijim državama članicama EU-a nedostaje radnika za održavanje gospodarskog rasta i ublažavanje učinaka starenja stanovništva. Neka od tih gospodarstava, predvođenih Njemačkom, tradicionalno se oslanjaju na strane, uglavnom nisko kvalificirane »gostujuće radnike«. Snažan rast i potražnja za radnicima u tim državama u vrijeme velike nezaposlenosti u državama članicama pogođenim krizom pojačala je nedavne migracije.

Treći čimbenik koji objašnjava veliku mobilnost unutar EU-a povezan je $s$ kvalitetom institucija i političkom klimom. Pojedinci se često odluče iseliti u potrazi za boljim životom i za sebe i za svoju djecu. Iseljenici, posebno oni s određenim vještinama/kvalifikacijama, sele se iz država sa slabim institucijama u one s jačima. Općenito govoreći, kvaliteta institucija važniji je čimbenik za kvalificirane migrante, dok nekvalificirane više privlače socijalne koristi koje mogu steći u državi u koju dolaze (Atoyan i sur., 2016).

Osim toga zadovoljstvo životom još je jedan važan pokretač iseljavanja. Ono uključuje nekoliko dimenzija, kao što su zadovoljstvo životnim standardom, mogućnosti za djecu, zadovoljstvo prihodima domaćinstva i povjerenje u nacionalne izbore i institucije. Godišnje izvješće za 2018. godinu Zajedničkoga istraživačkog centra Europske komisije (Joint Research Centre) o namjerama iseljavanja otkriva da nezadovoljstvo životnim standardom povećava vjerojatnost da će pojedinac željeti i planirati preseljenje u inozemstvo (Triollet i sur., 2019).

Važnost zadovoljstva životom kao pokretačem migracije potvrđena je u velikom broju država članica, poput Hrvatske. Prema istraživanju o suvremenom iseljavanju iz Hrvatske $u$ Njemačku, glavni motivi za iseljavanje nisu ekonomski, već socijalni i politički (Jurić, 2017). Rezultati istraživanja upućuju na povezanost političke etike, slabih institucija i iseljavanja. Glavni je pokretač iseljavanja to što se u Hrvatskoj radna etika i poštenje ne cijene. Istraživanje nadalje pokazuje da populaciju migranata čine uglavnom mlađe osobe koje su prethodno bile zaposlene u Hrvatskoj i koje se najčešće sele s cijelom obitelji (supružnikom, djecom). Većina novih iseljenika vrlo je zadovoljna svojom odlukom i ne žali zbog odlaska. 
Nedavno istraživanje Hrvatske udruge poslodavaca iz lipnja 2018., koje je provela Promocija Plus (2018) na uzorku od 661 hrvatskog iseljenika, potvrđuje ove nalaze. Istraživanje upućuje na tri skupine razloga zbog kojih hrvatski građani odlaze. Upadljivo je da prva skupina razloga, povezanih s nezadovoljstvom iseljenika socijalnim i političkim stanjem u Hrvatskoj, čini $65,5 \%$ osnova za iseljavanje. Najčešći razlozi u toj skupini jesu: neorganizirano stanje i nedostatak političke vizije, nepotizam, korupcija, vjerska netolerancija i nacionalizam te nedostatak strukturnih reformi. Druga skupina razloga, vezana uz radne uvjete, i treća skupina, vezana uz osobnu situaciju, čine preostalih 35\%. Najčešći su razlozi osjećaj da se rad i sposobnosti pojedinca ne cijene te niska ili neredovita isplata plaća.

\subsection{Učinci kretanja radnika unutar Europske unije}

Snažno iseljavanje i znatan gubitak ljudskoga kapitala u državama podrijetla doveli su do velikog nezadovoljstva i potaknuli mnoge analize kratkoročnih i dugoročnih učinaka iseljavanja. ${ }^{6}$ Ovo poglavlje opisuje pozitivne i negativne učinke slobodnoga kretanja radnika na pojedince, na Europsku uniju u cjelini te na države članice podrijetla i države primateljice. Zaključci upućuju na općenito pozitivne učinke na osobe koje su se preselile, na EU i na države primateljice. No za države članice podrijetla prevladavaju negativni učinci.

\subsubsection{Pojedinci}

Odluku o preseljenju pojedinci donose kako je opisano $u$ prethodnom odjeljku. Pojedinci se sele u potrazi za boljim radnim mogućnostima i bježe od negativnih pojava u svojim državama podrijetla. Iako se migranti često suočavaju s troškovima i poteškoćama u prilagođavanju novoj sredini, što uključuje trošak vezan uz preseljenje, učenje jezika i običaja te ponovno započinjanje karijere, često ispod razine svojih obrazovnih dostignuća, mnogi se građani EU-a uspijevaju prilagoditi novim sredinama, u kojima ostvaruju veća primanja i standard nego u svojim državama podrijetla. Širenje iseljeničkih mreža pomaže migrantima u tom prilagođavanju, dok se njihova djeca, koja pohađaju tamošnje škole, većinom brzo naviknu na novu sredinu. Osobe koje se teško prilagođavaju novoj sredini imaju mogućnost

6 Na primjer Međunarodni monetarni fond objavio je istraživanje Atoyana i sur. (2016), Europska banka za obnovu i razvoj (2018) analizirala ga je u svome godišnjem Izvješću o tranziciji 2018. - 2019., a rumunjsko predsjedništvo EU-a naručilo je studiju Alcidi i Gros (2019). 
povratka, posebno u uvjetima rastuće potražnje za radnicima i povećanja životnog standarda u novim državama članicama. To pak rad u inozemstvu čini manje atraktivnim za mnoge ekonomske migrante. Povratka iseljenika (kružna migracija) prisutan je u nekoliko novih država članica od 2017. (Chaffin, 2017). U nekim slučajevima iseljenici mogu steći novo iskustvo, znanje, poslovne kontakte i kapital tijekom rada u inozemstvu s kojima se mogu vratiti u svoje države podrijetla, a koji im mogu pomoći da pokrenu posao ili ostvare veću produktivnost i prihod po povratku (Bahar i sur., 2019).

\subsubsection{Europska unija}

Učinkovita upotreba resursa pretpostavlja da se oni upotrebljavaju na najproduktivniji način. Iz te perspektive, treba poticati kretanje radnika u područja koja omogućuju da se postojeća radna snaga na razini EU-a uposli na što produktivniji način. Radnicima iz novih država članica korisno je emigrirati i zaposliti se $u$ industrijama s visokom dodanom vrijednošću, koja se nalazi u razvijenim, starim državama članicama poput Njemačke. To međutim najviše pogoduje državama u koje radnici dolaze, pridonoseći njihovu rastu i blagostanju.

Slobodno kretanje radnika važno je i za funkcioniranje monetarne unije. U slučaju asimetričnog šoka problemi povećane nezaposlenosti u pogođenom dijelu mogu se smanjiti iseljavanjem radnika. ${ }^{7}$

Konačno, slobodno kretanje osoba u Uniji jača europski identitet i međukulturni dijalog. To međutim može imati i negativne učinke. Domaće stanovništvo može se osjećati ugroženo zbog useljenika, koje doživljava kao strance zbog drugačijeg jezika i običaja, i kao konkurenciju na tržištu rada te u primanju javnih usluga i transfera. ${ }^{8}$

\subsubsection{Države članice primateljice}

Države članice primateljice imaju znatne koristi od useljavanja. Novi radnici omogućuju rast gospodarstava suočenih s nedostatkom radne snage. Do-

\footnotetext{
Iako se literatura o optimalnome valutnom području fokusira na kretanje radnika unutar monetarne unije, nedavna kretanja sugeriraju sličnu ulogu imigracije iz država članica izvan eurozone. Nedavno useljavanje radnika izvan eurozone usporilo je rast plaća i cijena u Njemačkoj (Deutsche Bundesbank, 2018), što je omogućilo ekspanzivniju monetarnu politiku.

8 Snažan priljev radnika iz novih država članica nakon pristupanja doveo je do izraza »poljski vodoinstalater « u Velikoj Britaniji, prikazujući konkurenciju stranih radnika u profesijama koje su prethodno zauzimali radnici iz niže i srednje klase, smanjujući im primanja.
} 
lazak novih radnika stvara dodatnu potražnju za dobrima i uslugama, što dodatno povećava potražnju za radom. Veća porezna baza olakšava demografsku tranziciju (starenje stanovništva) i smanjuje trošak postojećih mirovinskih sustava međugeneracijske solidarnosti (pay-as-you-go), koji se suočavaju s rastućim brojem umirovljenika, te općenito olakšava financiranje javnih dobara i usluga. Usto, useljenici sa sobom donose značajan kapital, kako u novčanom obliku radi financiranja troška preseljenja tako i u obliku tzv. ljudskoga kapitala, koji je stvoren javnim i privatnim ulaganjima u njihovo obrazovanje u državi podrijetla. Dolazak velikog broja obrazovanih radnika, posebno strukovnih radnika poput medicinskih sestara, umanjuje potrebu za obrazovanjem takvih radnika u državama primateljicama, što smanjuje javnu potrošnju u tom području. ${ }^{9}$

\subsubsection{Države članice podrijetla}

Iseljavanje može biti korisno čak i za države podrijetla te za preostalo stanovništvo. Odlazak radnika povećava mogućnosti zaposlenja i plaće preostalih radnika u državi podrijetla. Iseljavanje je često popraćeno značajnim novčanim doznakama, kako u obliku transfera članovima obitelji (roditeljima i djeci) tako i ulaganjem zarađenih dohodaka u države podrijetla. Radnici koji se vraćaju također mogu donijeti vještine, poslovna poznanstva i kapital koji omogućuju brži ekonomski rast (Bahar i sur., 2019).

No snažno iseljavanje ima značajne negativne učinke, posebno u slučaju negativnoga prirodnog kretanja i demografskih projekcija. U studiji utjecaja nedavne emigracije iz Srednje i Istočne Europe Atoyan i sur. (2016) proučavali su učinke na gospodarski rast i konvergenciju, konkurentnost i fiskalne rezultate.

Iseljavanje smanjuje potencijalnu proizvodnju u državama podrijetla kroz smanjenje raspoložive radne snage. To se posebno odnosi na iseljavanje visoko kvalificiranih radnika, kojih ionako nedostaje u mnogim novim državama članicama. ${ }^{10}$ Nakon godina visoke nezaposlenosti u državama Srednje i Istočne Europe, uzrokovane tranzicijom i nedavnom krizom, nedostatak (kvalificiranih) radnika postaje značajno ograničenje za rast. Atoyan i sur.

9 Neki dokazi upućuju na to da Njemačka tijekom posljednjih nekoliko godina ulaže manje u obrazovanje medicinskih sestara, zbog snažnog useljavanja medicinskih sestara iz novih država članica.

10 Tradicionalna literatura o migracijama uglavnom se bavi pitanjem odljeva mozgova kretanjem najobrazovanijih iz manje razvijenih zemalja. No Alcidi i Gros (2019) pokazuju da su migranti iz najugroženijih država članica slični ili ispod prosjeka obrazovanja u odnosu na ukupno stanovništvo tih država. 
(2016) procjenjuju da je iseljavanje smanjilo godišnju stopu rasta za 0,6 do 0,9 postotna boda u najugroženijim državama članicama od 1999. do 2014. One također gube i tzv. aglomeracijski doprinos, gdje brojno visokoobrazovano stanovništvo omogućuje razvoj aktivnosti s većom dodanom vrijednošću. Niži potencijalni rast i usredotočenost na aktivnosti niske dodane vrijednosti ugrožavaju konvergenciju tih država.

Snažno iseljavanje može smanjiti konkurentnost država podrijetla (Atoyan i sur., 2016). Nedostatak kvalificiranih radnika dovodi do bržeg rasta plaća od produktivnosti. Inozemni transferi mogu preostale članove obitelji obeshrabriti da rade i time dodatno smanjiti ponudu radne snage. Usto, inozemne doznake potiču jačanje tečaja nacionalne valute, što smanjuje njihovu izvoznu konkurentnost. Stoga D'Adamo i sur. (2019) upozoravaju da nedavni rast plaća i značajne inozemne doznake u novim državama članicama upućuju na smanjenje njihove konkurentnosti.

Iseljavanje utječe i na javne financije. Slabija gospodarska aktivnost smanjuje proračunske prihode, dok ih doznake povećavaju. Atoyan i sur. (2016) zaključuju kako je do sada iseljavanje imalo samo mali i privremeni utjecaj na proračune novih država članica. No ono je utjecalo na porast udjela javne potrošnje u odnosu na veličinu njihovih gospodarstava i povećalo udio rashoda povezanih sa starenjem.

Države članice mnogo ulažu u obrazovanje svojih stanovnika (javna i privatna sredstva), tako da odlazak kvalificiranih radnika predstavlja značajan kapitalni transfer među državama članicama. Siromašnije države šalju ljudski kapital u bogatije države članice, što je suprotno od smjera koji potiče kohezijska politika. To je posebno problem u slučaju stručnih i kvalificiranih radnika, poput medicinskih sestara i liječnika, gdje su čitave generacije stručnjaka otišle u bogatije države članice.

Iseljavanje je dodatno pogoršalo ionako loše demografske projekcije. Nove države članice suočavaju se s padom broja stanovnika zbog naslijeđene niske stope fertiliteta i starenja stanovništva. Odlazak mlađih građana dodatno ubrzava starenje stanovništva. Osim širega ekonomskog učinka gubitka vitalnog dijela stanovništva (obrazovanog, poduzetničkog i reproduktivnog) iseljavanje povećava srednjoročne troškove starenja stanovništva, stvarajući dodatni pritisak na oporezivanje preostaloga aktivnog stanovništva, koje se smanjuje. 


\section{ODGOVOR DRŽAVA ČLANICA I EUROPSKE UNIJE NA NEGATIVNE UČINKE SLOBODNOGA KRETANJA}

Najčešći pokretači kretanja radne snage unutar EU-a pokazuju da nacionalne vlasti u državama članicama iz kojih se stanovništvo iseljava mogu puno učiniti na smanjenju iseljavanja. Drugim riječima, uklanjanjem nezadovoljstva ekonomskom, socijalnom i političkom situacijom manji broj osoba bit će potaknut na iseljavanje. No fiskalni poticaji samo su neke od mjera koje mogu potaknuti domaće državljane na ostanak u državi podrijetla, tj. povratak u nju. Osjećaj prosperiteta za sebe i svoju djecu ne može se u potpunosti ostvariti kroz veće plaće i druge financijske poticaje ako ih ne prate strukturne reforme nužne za šire ekonomsko i socijalno blagostanje. Stoga je poticaj stanovništvu na ostanak - barem za sada - prvenstveno unutarnja zadaća pojedinih država članica. Osiguranje odgovarajuće zdravstvene zaštite, standarda stanovanja, obrazovanja i drugih javnih dobara i usluga, kao i poslovno i javno okruženje lišeno korupcije i birokracije, i dalje su odgovornost nacionalnih, regionalnih i lokalnih vlasti. Istodobno su upravo lokalne i regionalne vlasti u najboljem položaju da prepoznaju i pokrenu aktivnosti za poticanje regionalne kohezije.

Ipak, postoji velik potencijal na europskoj razini za jačanje kohezije i, posljedično, smanjenje negativnih posljedica slobodnoga kretanja. Sljedeće poglavlje opisuje postojeće prijedloge i aktivnosti na nacionalnoj i europskoj razini. Predložene su i dodatne mjere u okviru nacionalnih i europskih politika za smanjenje negativnih učinaka slobodnoga kretanja radnika.

\subsection{Nacionalne inicijative}

Ozbiljnosti i opseg negativnih posljedica slobode kretanja na države koje bilježe veliko iseljavanje prepoznali su brojni istraživači, stručnjaci i nositelji politika na nacionalnoj i europskoj razini. Dosad je Rumunjska bila najglasnija u isticanju negativnih učinaka slobodnoga kretanja na države podrijetla. ${ }^{11}$ To ne iznenađuje s obzirom na to da, kako je opisano u drugom odjeljku, Rumunjska bilježi najveću stopa iseljavanja u druge dijelove EU-a: 21,3\% ili 2,5 milijuna njezina radno sposobnog stanovništva živjelo je 2018. izvan Rumunjske, što je ogroman teret za ekonomski rast i društveno blagostanje.

U studenom 2018. rumunjski ministar financija g. Teodorovici u govoru u parlamentu predložio je vremensko ograničenje za slobodno kretanje radnika, sugerirajući da pojedincima treba dopustiti da rade u drugoj državi

11 Više pojedinosti o aktivnostima Rumunjske u tom kontekstu: poglavlje 3.2. 
članici najviše pet godina, nakon čega bi se trebali vratiti u svoju matičnu državu (Romanian Minister suggests..., 2018). Nakon što je oštro iskritiziran zbog svoje izjave, g. Teodorovici pokušao je objasniti da nije namjeravao dovesti u pitanje temeljne slobode ili ograničiti prava rumunjskih državljana, već upozoriti na problem sporijega gospodarskog rasta i razvoja s kojim se Rumunjska suočava zbog iseljavanja (Romanian Minister suggests..., 2018). Gospodin Teodorovici nije osamljen u svojim strahovima i kontroverznim idejama. Prema anketi Europskog vijeća za vanjske odnose (ECFR), u Rumunjskoj, Poljskoj, Mađarskoj, Italiji, Španjolskoj i Grčkoj stanovništvo se više boji iseljavanja nego useljavanja (Zerka, 2019). Više od 50\% glasača u Italiji, Španjolskoj i Grčkoj smatra da bi građane trebalo spriječiti da napuštaju zemlju na duže razdoblje (Rice-Oxley i Rankin, 2019).

Države članice koje se suočavaju sa snažnim iseljavanjem pribjegavaju različitim metodama rješavanja nestašice radne snage i drugih negativnih učinaka slobodnoga kretanja. Neke su uvele porezne olakšice i druge fiskalne i nefiskalne poticaje usmjerene na smanjenje negativnih učinaka slobode kretanja. Na primjer tijekom posljednjih nekoliko godina Hrvatska je smanjila porezno opterećenje fizičkih i pravnih osoba, a predlažu se i dodatne porezne olakšice za mlade radnike kako bi se obeshrabrilo iseljavanje.

Bolje korištenje preostale radne snage može donekle nadoknaditi probleme nastale zbog odlaska radnika. Povećanje dobi za odlazak u mirovinu i poticanje rada na određeno vrijeme za umirovljenike može povećati ponudu radne snage. Usto, mnoge države Srednje i Istočne Europe suočavaju se s niskim stopama participacije na tržištu rada radno sposobnog stanovništva, posebno žena, tako da postoji velik broj potencijalnih radnika koji bi se mogli aktivirati. ${ }^{12}$

Mnoge države članice Srednje i Istočne Europe povećale su broj radnih dozvola za radnike iz trećih zemalja. Na primjer u Hrvatskoj je za 2019. godinu odobreno 65.100 radnih dozvola za zapošljavanje državljana trećih zemalja, od čega 50.100 novih radnih dozvola te 15.000 produljenja postojećih. ${ }^{13}$ Vlada Republike Hrvatske za 2020. godinu planira rekordan broj radnih dozvola: ukupno 78.470, od čega 64.604 nove radne dozvole i 25.000 produljenja postojećih. ${ }^{14}$ Iako se razmišljalo o potpunom ukidanju kvota već

12 Više o potencijalnom rastu i tržištu rada vidi u »Izvješću o starenju« Europske komisije (2018c).

13 Odluka o utvrđivanju godišnje kvote dozvola za zapošljavanje stranaca za kalendarsku godinu 2019., Narodne novine, 116/2018.

14 Odluka o utvrđivanju godišnje kvote dozvola za zapošljavanje stranaca za kalendarsku godinu 2020., Narodne novine, 113/2019. 
za 2020. godinu (Miličić, 2019), to se nije dogodilo, ali se, prema informacijama dobivenim usmenim putem od nadležnih hrvatskih tijela, može očekivati potpuno ukidanje kvota za 2021. Osim toga od osamostaljenja 1991. Hrvatska je dodijelila hrvatsko državljanstvo etničkim Hrvatima koji žive u inozemstvu, većinom u Bosni i Hercegovini. Time je omogućila veliko useljavanje iz Bosne i Hercegovine i drugih bivših jugoslavenskih republika, posljedično povećavajući vlastito stanovništvo i automatski omogućujući svim etničkim Hrvatima pristup unutarnjem tržištu EU-a.

Poljska je omogućila dolazak ukrajinskim radnicima kao zamjene za domaće državljane otišle u Njemačku i druge članice EU-a. Procjena broja Ukrajinaca u Poljskoj varira od nekoliko stotina tisuća do dva milijuna (Walker, 2019). Odbojnost prema imigrantima, koja prevladava u mnogim državama Srednje i Istočne Europe, bila je u ovom slučaju manje važna, zbog kulturne, vjerske i fizičke sličnosti Ukrajinaca s Poljacima.

S druge strane, odbojnost vlasti prema imigrantima bila je glavni pokretač mjera poduzetih u državama poput Mađarske. U veljači 2019. mađarski premijer Viktor Orban predstavio je program u sedam točaka, s primarnim demografskim ciljem povećanja domaćega, mađarskog stanovništva. Program uključuje zajam od deset milijuna forinti (otprilike 30.680 eura) ženama mlađim od četrdeset godina koje se prvi put udaju. Trećina zajma treba se otpisati nakon rođenja drugog djeteta, a cijeli bi se iznos otpisao nakon trećeg djeteta, dok žene s četvero i više djece ne bi morale plaćati porez na dohodak (Hungary gives tax breaks..., 2019). Osim toga program premijera Orbana predviđa smanjenje otplata stambenih kredita i kredita za kupnju automobila za roditelje, uvođenje novih zajmova za obitelji, mogućnost djedovima i bakama da koriste/dijele rodiljni dopust te povećanje broja mjesta u vrtićima (Kingsley, 2019).

Ovi primjeri pokazuju da je većina do sada poduzetih nacionalnih mjera fiskalne prirode. No dosadašnje iskustvo i opisana istraživanja pokazuju da fiskalni poticaji - bez dubljih strukturnih reformi usmjerenih povećanju ekonomskoga i društvenog blagostanja - nisu dovoljni za odvraćanje stanovništva od iseljavanja. ${ }^{15}$ Istina je međutim da će se dio iseljenika vratiti u države podrijetla. To je dijelom posljedica nezadovoljstva životnim uvjetima u državi primateljici, koje je iskusio dio iseljenika, a dijelom posljedica

Vidi Alcidi i Gros (2019) te prilog o »Radu u tranziciji« iz EBRD-ova Izvješća o tranziciji 2018.-2019. (Europska banka za obnovu i razvoj, 2018: 67) koje sugerira da "poboljšanje poslovnog okruženja i kvalitete javnih usluga može značajno smanjiti potrebu ljudi da iseljavaju «. 
postupnog smanjenja razlika u plaćama između država podrijetla i država primateljica. Fenomen kružne migracije već se nazire, u čemu prednjače Poljaci, koji se počinju vraćati iz zapadnoeuropskih zemalja, pretežno Velike Britanije, dijelom zbog Brexita, a dijelom potaknuti poljskim ekonomskim rastom i novim mogućnostima (Chaffin, 2017).

\subsection{Inicijative $i$ istraživanja na razini Europske unije}

Rumunjska, kao država članica koja je najviše pogođena iseljavanjem, iskoristila je svoje predsjedanje Vijećem ministara u prvoj polovini 2019. kako bi istaknula negativne učinke slobode kretanja radnika na neformalnom Ecofinu održanom 6. travnja 2019. u Bukureštu. Tada je ministar Teodorovici upozorio na negativne učinke kretanja radnika objašnjavajući da je »to slučaj kad je mobilnost selektivna, što dovodi do odljeva mozgova i usporavanja potencijalnog rasta«. Zaključio je tvrdnjom da je »u bliskoj budućnosti, naš [europski] prioritet naći zajedničko rješenje na europskoj razini i provesti mjere koje bi nam pomogle pri rješavanju tog problema« (Teodorovici, Priopćenje za javnost s neformalnog Ecofina, 2019).

Za neformalni sastanak Ecofina rumunjsko predsjedništvo naručilo je istraživanje o nedavnom kretanju radnika u EU-u i fiskalnim izazovima koje ono stvara u državama podrijetla. To istraživanje, koje su proveli Alcidi i Gros (2019), sugerira da neučinkovita javna potrošnja i teškoće s pružanjem kvalitetnih javnih usluga povećavaju vjerojatnost odlaska. Iako Alcidi i Gros ne daju izričite preporuke, gore navedena izjava i zaključak da će »uz kontinuirano smanjenje razlika u plaćama razlike u strukturnim faktorima u budućnosti biti važnije od neto plaća pri donošenju odluke o iseljavanju « (Alcidi i Gros, 2019: 8) sugeriraju da su strukturna poboljšanja i povećanje kvalitete javnih dobara glavni čimbenici koji mogu smanjiti iseljavanje.

Drugo istraživanje koje su proveli Cavallini i sur. (2018), a koje je naručilo Povjerenstvo za socijalnu politiku, obrazovanje, zapošljavanje, istraživanje i kulturu (SEDEC) Europskog odbora regija, upotrijebilo je primjere 30 uspješnih inicijativa u 22 države članice za izradu preporuka o mjerama koje lokalne i regionalne vlasti mogu primijeniti kako bi zadržale i privukle visokoobrazovane radnike. Činjenica da su preporuke upućene lokalnim i regionalnim vlastima, naglašava njihovu ulogu, kao i posljedice kretanja radnika na lokalnoj i regionalnoj razini. Preporuke su široke prirode kako bi se mogle upotrijebiti u različitim regijama i okolnostima, a koncentrirane su na poboljšanje regionalnih politika koje se ogledaju u privlačnosti regije za mlade i talentirane radnike. Preporuke SEDEC-a sugeriraju da regije 
i gradovi trebaju: bolje prepoznati potrebe talenata, na primjer uspostavljajući dijalog s mladima; poboljšati koordinaciju s relevantnim strankama koji imaju koristi od talenta na lokalnom teritoriju; identificirati i podržati ključne sektore za zadržavanje/privlačenje talenata; potaknuti zapošljavanje vanjskih talenata; ublažiti/ukloniti strukturne prepreke za privlačenje međunarodnih talenata; i surađivati s drugim vlastima koje se suočavaju $\mathrm{s}$ istim izazovima u pogledu visokokvalificiranih radnika (Cavallini i sur., 2018: 71-78).

\subsection{Mjere Europske unije: doseg fondova i Europski stup socijalnih prava}

Mjere na razini EU-a koje su neizravno povezane sa smanjenjem negativnih posljedica kretanja radnika dvostruke su. Prije svega, Europski strukturni i investicijski fondovi - prvenstveno Kohezijski fond i Europski fond za regionalni razvoj - usmjereni su na gospodarsku i socijalnu koheziju promicanjem razvoja siromašnijih regija. Jedan od učinaka takve regionalne potpore i razvoja jest smanjenje poticaja za iseljavanje u razvijenije države članice. No proces konvergencije se usporio, osobito nakon financijske krize. Dodatno, raspoloživi iznosi u okviru Kohezijskog fonda i Europskog fonda za regionalni razvoj nisu dovoljni da omoguće jaču konvergenciju.

Usto, neke siromašnije države članice nisu bile uspješne u upotrebi sredstava iz europskih fondova. Hrvatska, kao najmlađa i najneiskusnija država članica, do sada nije bila posebno uspješna u upotrebi dostupnih sredstava. Takvo iskustvo nije novo, jer su se mnoge nove države članice mučile s apsorpcijom nakon pristupanja. Od 2014. do 2020. Hrvatskoj je iz europskih strukturnih i investicijskih fondova dodijeljeno 10,7 milijardi eura. ${ }^{16} \mathrm{Od}$ tog iznosa 8,43 milijarde eura usmjereno je na mjere kohezijske politike. No do kraja listopada 2017. Hrvatska je ugovorila samo oko 30\% tog iznosa, dok je krajnjim korisnicima isplaćeno samo 7\% (Brkljača, 2017). Podaci iz 2018. pokazuju porast apsorpcijske sposobnosti u Hrvatskoj (Ministarstvo regionalnog razvoja i fondova EU, 2019). Pozitivan trend vjerojatno će se nastaviti rastom i sazrijevanjem znanja i iskustva nacionalnih tijela u postupku apsorpcije.

No prijedlog Europske komisije (2018b) o reformi Kohezijskog fonda za sljedeće proračunsko razdoblje vjerojatno će dovesti do smanjenja sredstava

16 Ministarstvo regionalnog razvoja i fondova EU, https://razvoj.gov.hr/hrvatskoj-na-raspolaganju-10-7-milijardi-eura-iz-eu-fondova/1917. 
Kohezijskog fonda i uvođenja novih kriterija za njegovu raspodjelu, poput primitka i integracije migranata. Budući okvir Kohezijskog fonda za novo proračunsko razdoblje također će vjerojatno sniziti doprinos EU-a s 85 na 70 posto i uključiti dodatne faktore u izračun kohezijskog izdvajanja, poput primitka migranata, što ne pogoduje većem broju država članica suočenih s iseljavanjem, uključujući i Hrvatsku (Rios, 2018). Može se očekivati da će odluka o smanjenju Kohezijskog fonda - umjesto njegova povećanja - i dodatni uvjeti za njegovu upotrebu znatno otežati nacionalne i regionalne napore za smanjenje negativnih posljedica mobilnosti unutar EU-a.

Druga kategorija mjera na europskoj razini vezana je uz Europski stup socijalnih prava (ESSP). ESSP je neobvezujući pravni instrument (soft law) koji su proglasili Europski parlament, Vijeće i Komisija na Socijalnom samitu EU-a u Göteborgu 17. studenog 2017. ${ }^{17}$ Sadržava dvadeset načela usmjerenih na podršku kvalitetnom funkcioniranju tržišta rada i sustava socijalne skrbi. ${ }^{18}$ Načela su strukturirana u tri kategorije: jednake mogućnosti i pristup tržištu rada, pošteni radni uvjeti te socijalna zaštita i uključenost. ${ }^{19}$ Neka od tih načela već su prisutna u zakonodavstvu EU-a, pa je cilj ESSPa - uz dodatak novih načela i prava - povećati njihovu vidljivost. ${ }^{20}$ Ideja uspostave ESSP-a jest postići »visokokonkurentno tržišno gospodarstvo $\mathrm{s}$ ciljem pune zaposlenosti i društvenog napretka«, kako je predviđeno člankom 3(3) Ugovora o Europskoj uniji (UEU). Stoga je promocija socijalne Europe i socijalne kohezije okosnica ESSP-a.

17 Europski stup socijalnih prava prvi je put predložio tadašnji predsjednik Komisije Juncker u svom govoru o stanju Unije 2015. Komisija je predstavila prvi nacrt Stupa u ožujku 2016. i pokrenula javnu raspravu, koja je završena završnom konferencijom u siječnju 2017.

18 Vidi točku 14. preambule Europskog stupa socijalnih prava, dostupne na: https:// ec.europa.eu/commission/sites/beta-political/files/social-summit-european-pil-socialrights-booklet_en.pdf (20. 7. 2019.). Vidi i izjavu predsjednika Junckera, potpredsjednika Dombrovskisa i povjerenika Thyssena godinu dana nakon proglašenja Europskog stupa socijalnih prava, 13. studenog 2018., http://europa.eu/rapid/press-release_STATEMENT-18-6390_en.htm (20.7. 2019.).

19 Dvadeset načela jesu: obrazovanje, osposobljavanje i cjeloživotno učenje; rodna jednakost; jednake mogućnosti; aktivna potpora zapošljavanju; sigurno i prilagodljivo zaposlenje; plaće; informacije o uvjetima zaposlenja i zaštita u slučaju dobivanja otkaza; socijalni dijalog i uključenost radnika; ravnoteža između poslovnog i privatnog života; zdravo, sigurno i dobro prilagođeno radno okruženje te zaštita podataka; skrb o djeci i potpora djeci; socijalna zaštita; prava za vrijeme nezaposlenosti; minimalni prihod; dohodak u starosti i starosna mirovina; zdravstvena skrb; uključenost osoba s invaliditetom; dugotrajna skrb; stanovanje i pomoć beskućnicima; i pristup osnovnim uslugama (vidi knjižicu Europskog stupa socijalnih prava).

20 Vidi točku 14. preambule Europskog stupa socijalnih prava. 
Veza između Europskog stupa socijalnih prava i smanjenja negativnih posljedica slobodnoga kretanja dvostruka je. Prije svega, snažnija primjena ESSP-a može smanjiti iseljavanje iz siromašnijih država članica i regija smanjujući neke od najčešćih razloga za iseljavanje. S druge strane, ESSP bi mogao smanjiti negativne posljedice slobodnoga kretanja osiguranjem minimalne razine socijalnih prava u cijelom EU-u, bez obzira na nastanak ekonomskih, demografskih ili socijalnih izazova/kriza.

No upitno je u kojoj je mjeri Europski stup socijalnih prava do sada poboljšao socijalna prava i pridonio socijalnoj konvergenciji. ${ }^{21}$ Zbog podjele nadležnosti provedba većine načela navedenih u ESSP-u ovisi o državama članicama i njihovim regionalnim i lokalnim vlastima, pri čemu drugi socijalni partneri također igraju važnu ulogu. ${ }^{22}$ Zbog svoje neobvezujuće pravne prirode i oslanjanja na nacionalne, regionalne i lokalne vlasti provedba ESSP-a ovisi o volji, sposobnosti i financijskim sredstvima država članica. ${ }^{23}$ Uzimajući u obzir velike, prvenstveno financijske, ali i socijalne i političke razlike među državama članicama, postizanje dogovora o minimalnoj plaći na razini cijelog EU-a teško je ostvarivo.

Zanimljivo je da je potpuna provedba Europskog stupa socijalnih prava, koja bi uključivala okvir za poštenu minimalnu plaću na razini EU-a, postavljena kao jedan od prioriteta u kandidatskom programu Ursule von der Leyen, koji je predstavila u svojoj uvodnoj izjavi u Europskom parlamentu 16. srpnja 2019., neposredno prije nego što je izabrana (Von der Leyen, 2019a). Iako gospođa Von der Leyen nije precizirala kako namjerava postići taj cilj, čini se da ne planira pravno obvezujuću mjeru, već samo opći dogovor na razini EU-a (naziva ga »okvirom«) (Von der Leyen, 2019b) o nacionalnim zakonodavnim mjerama ili kolektivnim ugovorima usvojenim »u skladu s nacionalnom tradicijom « putem socijalnog dijaloga između poslodavaca i sindikata (Von der

${ }^{21}$ Za analizu potencijala Europskog stupa socijalnih prava vidjeti Vanhercke, B., Sabato, S. i Ghailani, D. (2018). Za prijedloge kako nadograditi socijalnu stečevinu EU-a vidjeti Garben, S., Kilpatrick, C. i Muir, E. (2017).

22 S tim u vezi vidi točku 17. Preambule Europskog stupa socijalnih prava, koja kaže da se Stup »treba provoditi na razini Unije i na razini države članice u okviru njihovih nadležnosti«, te točku 19. preambule, koja navodi da stup »poštuje raznolikost kultura i tradicija naroda Europe, kao i nacionalni identitet država članica i organizaciju njihovih javnih vlasti na nacionalnoj, regionalnoj i lokalnoj razini. Konkretno, uspostava Europskog stupa socijalnih prava ne utječe na pravo država članica da definiraju temeljna načela svojih sustava socijalnog osiguranja i upravljanje svojim javnim financijama te ne smiju značajno utjecati na njihovu financijsku ravnotežu«.

23 Za preporuke o tome kako učinkovito provoditi stup vidjeti »Implementing the European Pillar of Social Rights - Study«, Europski ekonomski i socijalni odbor, 30. ožujka 2018., https://www.eesc.europa.eu/sites/default/files/files/qe-01-18-612-en-n.pdf (20. 7. 2019.). 
Leyen, 2019b). To ne iznenađuje s obzirom na ograničenu nadležnost Unije u socijalnoj politici, uključujući izuzeće regulacije plaća iz socijalne politike EU-a predviđeno čl. 153(5) UFEU-a. ${ }^{24}$ Umjesto toga vjerojatno je da će Komisija uspostaviti okvir za postupanje država članica izdavanjem smjernica i drugih pravno neobvezujućih mjera, čime će se prebaciti odgovornost na nacionalna, regionalna i lokalna tijela te na socijalne partnere. ${ }^{25}$

Dodatna inicijativa novoizabrane predsjednice Komisije jest uspostava Europskog sustava reosiguranja naknada za nezaposlene, koji bi pružio bolju zaštitu onima koji izgube posao zbog vanjskih šokova. Gospođa Von der Leyen opet nije jasno navela parametre ovog programa. Na prvi pogled, program za nezaposlene izgleda kao važan mehanizam jačanja socijalne dimenzije EU-a i doprinos konvergenciji tržišta rada. Takav bi program mogao poboljšati zaštitu nezaposlenih i spriječiti siromaštvo (Beblavý i Lenaerts, 2017). To bi bilo posebno važno za siromašnije države članice u njihovoj borbi protiv negativnih posljedica slobodnoga kretanja. No, prema posljednjim informacijama o programu iz siječnja 2019., ideja nije uspostaviti novi financijski sustav, već uključiti program za nezaposlene u proračun Europske unije $u$ iznosu od trideset milijardi eura kroz program stabilizacijske funkcije, koji je u svojem prijedlogu novoga Višegodišnjeg financijskog okvira osmislila Europska komisija za države članice eurozone (koja je također otvorena i za ostale države članice) (Europska komisija, 2019). Malo je vjerojatno da će novoizabrana predsjednica Komisije odstupiti od skromnog pristupa Junckerove komisije. Osim toga, s obzirom na činjenicu da je gospođa Von der Leyen izabrana vrlo tijesnom većinom, malo je vjerojatno da će predlagati bilo kakve revolucionarne nove mjere i upitno je u kojoj će mjeri uspjeti održati svoja početna obećanja.

Čak i ako se uspostavi sustav osiguranja za nezaposlene, upitno je hoće li on biti dostupan svim državama članicama pod istim uvjetima, a ne samo članicama eurozone. Povrh toga, minimalna plaća i sustav osiguranja za slučaj nezaposlenosti sami po sebi ne mogu umanjiti negativne učinke slobode kretanja na najteže pogođene države članice. Strukturne reforme i povećanje sredstava predviđenih za javna dobra u okviru nacionalnih proračuna - bez obzira na to jesu li iz europskih fondova ili dobivena na neki drugi način - nužni su uvjet za postizanje istinskih promjena. ${ }^{26}$

24 Čl. 153(5) UFEU-a propisuje da se socijalna politika EU-a »ne primjenjuje na plaću«.

25 Za kritiku raspodjele odgovornosti vidi Rasnača (2019).

26 Povrh svega toga, Knijn (2019) tvrdi da, kako bi se Europski stup socijalnih prava shvatio ozbiljno, potrebno je obnoviti solidarnost s onima koji ne mogu sudjelovati na tržištu rada, a to treba učiniti povratkom političke kontrole i povećanjem proračuna za javne usluge. 


\section{ZAKLJUČNE NAPOMENE O BUDUĆIM OPCIJAMA}

Prethodna rasprava i stanje na terenu svjedoče da dosad primijenjene nacionalne i europske mjere nisu dovoljne za smanjenje negativnih učinaka slobode kretanja u najteže pogođenim državama članicama. Treba razmotriti nove instrumente s ciljem ublažavanja pokretača iseljavanja i kompenzacije država članica iz kojih se stanovništvo iseljava, a da se istovremeno ne ograničavaju temeljne slobode. Kao što je već naglašeno, sloboda kretanja jedno je od najpozitivnijih postignuća europske integracije, s mnoštvom pozitivnih učinaka za pojedince koji se kreću, države primateljice i za EU u cjelini. Svako smanjenje prava na slobodno kretanje ugrozilo bi integraciju Unije, njene vrijednosti i ekonomski prosperitet te se zato ne bi smjelo dogoditi. No negativni učinci slobode kretanja štetni su i treba ih ukloniti jer dovode do divergencije i ekonomskoga, socijalnog i političkog udaljavanja država članica.

To nas dovodi do dva pitanja. Prvo, treba razmisliti kako smanjiti negativne učinke slobode kretanja. No prije toga valja razmotriti treba li rješenja tražiti isključivo na nacionalnoj/ regionalnoj/lokalnoj razini, na razini EU-a, ili oboje. Autori smatraju da bi kombinacija nacionalnih/regionalnih/ lokalnih i zajedničkih europskih mjera bila najbolje rješenje. Tri su razloga za to. Prvo, usprkos činjenici da nacionalne, regionalne i lokalne vlasti imaju presudnu ulogu u ostvarivanju promjena, iskustvo pokazuje da one često nemaju dovoljno sredstava, stručnosti i/ili sposobnosti za djelovanje. Ovdje se može povući paralela sa sposobnošću lokalne i regionalne razine da riješe problem iseljavanja $u$ druge razvijenije regije unutar iste države članice. Iskustvo pokazuje da regionalne vlasti ne mogu riješiti taj problem bez pomoći s nacionalne razine. Međusobna povezanost i ovisnost između lokalnih/regionalnih i nacionalnih napora primjenjiva je i na odnose između nacionalnih i europskih politika. Države članice pogođene problemom iseljavanja ostvarit će puno bolje rezultate ako ih u tim nastojanjima podrži Europska unija u cjelini. Ipak, nacionalne, regionalne i lokalne vlasti, kao i socijalni partneri i civilno društvo, imaju važnu ulogu u rješavanju negativnih učinaka slobode kretanja. Stoga, svaka mjera na europskoj razini može ostvariti željene rezultate samo pod uvjetom da je popraćena nacionalnim i lokalnim djelovanjem i spremnošću za suradnjom.

Drugo, postoje pragmatični razlozi zašto bi Europska unija kao cjelina trebala sudjelovati u borbi protiv negativnih učinaka slobode kretanja. Siromašnije države članice i regije izložene su velikom iseljavanju, koje utječe na njihovo daljnje gospodarsko i socijalno osiromašenje te na koncentraci- 
ju visoko kvalificirane radne snage $u$ bogatijim državama članicama. To je u sukobu s idejom kohezije u EU-u. Usto, prekomjerno iseljavanje iz siromašnijih u bogatije države članice može imati negativne učinke ili stvoriti društvenu percepciju negativnih učinaka i u državama primateljicama. To može dovesti do pogoršanja uvjeta na tržištu rada (socijalnog dampinga) i straha od zloporabe socijalnih primanja. To također može stvoriti probleme $s$ integracijom useljenika i dovesti do porasta animoziteta. Ti procesi, koji se istodobno odvijaju u siromašnijim i bogatijim državama članicama, mogli bi stvoriti klimu koja naginje nacionalističkim i antieuropskim osjećajima, sklonu sve većim povredama vladavine prava i drugih vrijednosti Europske unije. Stoga sve države članice i institucije EU-a trebaju biti zainteresirane za smanjenje negativnih učinaka slobode kretanja.

Naposljetku, razlog za rješavanje ovog problema na europskoj razini može se pronaći u načelu solidarnosti i pravedne podjele odgovornosti. Solidarnost je složen pojam koji obuhvaća različite motive i aspekte (Goldner Lang, 2018a). Jedan je od tih aspekata »pravednost« (ili »pravda«), koja se temelji na osnovnoj pretpostavci da je Unija cjelina i da bi teret s kojim je suočena jedna država članica trebale dijeliti ostale države članice (Goldner Lang, 2018a). Pravednost je subjektivan pojam: ono što je pravedno za jednu osobu ne mora biti doživljeno na isti način od nekog drugog. No, budući da sloboda kretanja radnika u Europskoj uniji istovremeno proizvodi negativne učinke u jednoj i pozitivne učinke u drugoj državi članici, ili, drugim riječima, budući da sloboda kretanja rezultira dobitima nekih država članica na štetu drugih, čini se pravednim da države članice koje imaju koristi od slobode kretanja dijele teret s onima koje taj teret snose.

Autori smatraju da - zbog postojanja veze između koristi i troškova slobode kretanja, koje države članice ne dijele ravnomjerno - postoji obveza djelovanja na europskoj razini. Ta se obveza temelji na načelu solidarnosti i pravedne podjele odgovornosti, kao njezina sastavnog dijela. Veza između koristi i troškova slobode kretanja postoji zbog procesa transfera ljudskoga kapitala iz siromašnijih u bogatije države članice do kojeg dolazi prilikom iseljavanja. Iseljenici odnose svoja znanja, vještine i iskustva, stečena u jednoj državi članici, i upotrebljavaju ih u drugoj, pridonoseći tako dobrobiti društva u državi članici primateljici. Time se koristi od ulaganja u ljude putem obrazovanja, koje financiraju siromašnije države članice, prenose $u$ bogatije države članice. Umjesto procesa konvergencije, djelomično ostvarenog transferom kapitala iz razvijenijih u manje razvijene države članice, iseljavanje iz siromašnijih u bogatije države članice može se promatrati kao 
proces obrnutih transfera ili subvencija bogatih od siromašnih. Posljedično, taj je proces u suprotnosti s ciljevima kohezijske politike i treba ga rješavati na europskoj razini. Taj problem postoji usprkos činjenici da se dio kapitala vraća u države članice podrijetla putem privatnih investicija i novčanih sredstava koje u države podrijetla često šalju iseljenici.

Iz svih gore navedenih razloga postoji obveza Europske unije na djelovanje i pomoć državama članicama koje snose negativne posljedice slobode kretanja. To nas dovodi do drugog pitanja o tome što bi EU konkretno mogao učiniti za rješavanje ovog problema. Postoje tri skupine instrumenata koji bi se mogli upotrijebiti ili dalje razvijati i koji bi postigli najbolje učinke ako bi se kombinirali. Najočitije i vjerojatno najkontroverznije rješenje bilo bi da Europska unija i njene države članice promjenom postojećih pravila olakšaju useljavanje državljana trećih zemalja, čime bi se popunila radna mjesta i poboljšala demografska struktura. Zasad državljani trećih zemalja koji nisu obuhvaćene pravilima o međunarodnoj zaštiti imaju samo ograničen broj prava temeljem prava EU-a. Njihov status u najvećem broju slučajeva ostaje podložan nacionalnim pravilima države članice domaćina, koja su vrlo raznolika. Umjesto jedinstvenoga harmonizirajućeg akta Unije, koji bi obuhvatio prava svih državljana trećih zemalja u EU-u, Unija je izabrala sektorski pristup reguliranjem prava samo uskim i "poželjnim « kategorijama državljana trećih zemalja, koja države članice smatraju prihvatljivim (Golnder Lang, 2018b). ${ }^{27}$ Države članice zadržavaju isključivu nadležnost za utvrđivanje broja državljana trećih zemalja koje će u svrhu zapošljavanja i samozapošljavanja primiti na svoje nacionalne prostore. ${ }^{28}$ Unatoč činjenici da su neke države članice odlučile ublažiti nacionalna pravila o primitku određenih kategorija državljana trećih zemalja - kao što je to učinila Poljska za Ukrajince ${ }^{29}$ - društveni stavovi prema useljavanju državljana trećih zemalja u većini država članica ne omogućuju ozbiljan pomak u nacionalnim migracijskim politikama ili europskoj migracijskoj politici koji bi omogućio imigracije velikih razmjera.

27 Prava državljana trećih zemalja kodificirana su u mnogim sektorskim direktivama, npr. o članovima obitelji državljana EU (Direktiva 2004/38), o članovima obitelji legalno stanovanih državljana trećih zemalja (Direktiva 2003/86), stalni rezidenti (Direktiva 2003/109), o visokokvalificiranim zaposlenicima (Direktiva o plavoj kartici 2009/50), o radnicima državljana trećih zemalja koji legalno borave u državi članici (Direktiva 2011/98 o jedinstvenim dozvolama EU), o studentima, učenicima, istraživačima i suradnicima (Direktiva 2016/801), sezonskim radnicima (Direktiva 2014/36), unutar premještenim kvalificiranim osobama izvan EU-a (Direktiva 2014/66).

28 Članak 79(5) UFEU-a.

29 Vidi poglavlje 3.1 . 
Drugi bi pristup bio jačanje fiskalnih transfera državama članicama koje su najteže pogođene negativnim učincima slobode kretanja. To bi se moglo postići povećanjem transfera iz postojećih fondova i/ili osnivanjem novih fondova, poput fonda za nezaposlene na razini EU-a. ${ }^{30}$ No trenutačni pregovori o sljedećemu Višegodišnjem financijskom okviru ne daju puno nade u tom smjeru. Umjesto povećanja proračuna za europske strukturne i investicijske fondove, prijedlog Komisije o reformi Kohezijskog fonda smanjio bi raspoloživa sredstva i ugradio dodatne elemente za izračun kohezijskih alokacija, poput primitka i integracije migranata (Europska komisija, 2018b). ${ }^{31}$ Također se očekuje da će doprinos EU-a u troškovima kohezijskih programa biti smanjen s 85 na 70 posto (Rios, 2018). Države članice nisu spremne povećati svoj doprinos ionako nedovoljnom proračunu EU-a, dok se politički prioriteti EU-a usredotočuju na druga područja, poput sigurnosti i kontrole granica. Sve to ne ide u prilog nacionalnim i regionalnim naporima kojima bi se smanjili negativni učinci slobode kretanja.

Povrh toga, neadekvatna apsorpcija i moguća zloporaba europskih fondova, zbog korupcije i lošeg upravljanja u nekim državama članicama, dodatni je argument protiv povećanja ulaganja u Kohezijski fond. Takvo ponašanje također štetno djeluje na percepciju političke i društvene klime u siromašnijim državama članicama i potiče odluke za iseljenje. Ostaje otvoreno pitanje što EU može učiniti kako bi smanjio korupciju i loše upravljanje. Pokušaj Unije da prisili države članice na poštovanje vladavine prava - uključujući i najnoviju zakonodavnu inicijativu u tom području, koja uspostavlja vezu između povrede vladavine prava i obustave isplate sredstava iz europskih fondova uvjetovanjem isplate sredstava obvezom poštovanja vladavine prava - dio je napora EU-a usmjerenih na poboljšanje postojećeg stanja. ${ }^{32}$

30 Za raspravu o europskom shemi reosiguranja naknada za nezaposlene vidjeti poglavlje 3.3.

31 Povezujući kohezijsku i migracijsku politiku EU-a, EU i neke njegove države članice pokušavaju prisiliti one države članice koje su ovisne o sredstvima iz proračuna EU-a da više pridonose migracijskoj politici EU-a povećanjem broja tražitelja azila koje primaju i integriraju. To stajalište legitimiraju logikom sveobuhvatnog pristupa solidarnosti, na temelju kojeg bi sve države članice trebale ravnomjerno sudjelovati i pridonositi svim politikama EU-a, a ne odabirom samo onih koje im se sviđaju. U tom svjetlu valja pogledati nedavnu izjavu francuskog predsjednika Emmanuela Macrona da »Europa ne može biti a la carte kada se govori o solidarnosti« i da EU ne može imati države »koje kažu mi ne želimo nikakvu vašu Europu kada je riječ o podjeli tereta, ali mi to radimo kad je riječ o strukturnim fondovima« (vidi Zalan, 2019).

32 Prijedlog Uredbe o zaštiti proračuna Unije u slučaju općih nedostataka koji se tiču vladavine zakona u državama članicama, COM (2018) 324 final, 2. svibnja 2018. O Prijedlogu Uredbe, vidi Goldner Lang (2019). 
Čak i kada bi Europska unija, iznenađujuće, odlučila povećati sredstva kohezijskih fondova u svrhu kompenzacije siromašnih država članica zbog iseljavanja stanovništva u bogatije, postojao bi niz otvorenih pitanja koja bi trebalo riješiti. Prvo, nije jasno kako bi se računao transfer ljudskoga kapitala. Bilo bi potrebno osmisliti pravedan i zajednički prihvatljiv način izračuna koji bi obuhvatio troškove obrazovanja i druga ulaganja u osobe koje se isele. Drugo, valja razmisliti o tome tko bi bio odgovarajući primatelj naknade. Bi li novac trebalo uložiti u financiranje javnih usluga poput obrazovanja, zdravstva, javne sigurnosti i stanovanja ili bi ga trebalo upotrijebiti za povećanje plaća kako bi se smanjio jaz u plaćama između siromašnijih i bogatijih država članica? Ono što je najvažnije, fiskalni transferi nikad ne mogu u potpunosti nadoknaditi gubitak stanovništva. Na primjer financijskom kompenzacijom ne može se u potpunosti naknaditi odlazak medicinske sestre koja je napustila hrvatsku bolnicu i sada radi u Njemačkoj sve dok hrvatska bolnica ne nađe zamjenu. U suprotnom će u konkretnoj bolnici i dalje nedostajati medicinska sestra, što se odražava na opću kvalitetu zdravstvene zaštite u Hrvatskoj.

Konačno, treća opcija bila bi rekonceptualizacija građanstva Unije. Pomak $\mathrm{k}$ stvaranju pravog Europskog stupa socijalnih prava bio bi važan korak u tom smjeru. Ako građanstvo Unije definiramo na širi način, tada bi svim građanima EU-a, uključujući i one koji se ne sele u druge države članice, trebalo osigurati minimalne standarde socijalnih prava koji bi uključivali odgovarajući smještaj, hranu, zdravstvenu skrb, obrazovanje i socijalnu sigurnost. To bi značilo da bi Europska unija trebala dobiti veće ovlasti u području socijalnih prava građana Unije, pri čemu bi sredstva za osiguranje socijalnih prava trebala biti djelomično osigurana iz proračuna Europske unije. Kombinacija sustava u kojem bi EU imao veće ovlasti za uređivanje socijalnih prava i u kojem bi se istovremeno povećao njegov proračun, $\mathrm{u}$ svrhu provedbe proširenih ovlasti, pomogla bi siromašnijim državama članicama jer bi njihova ulaganja $u$ javne usluge bila djelomično financirana od razvijenijih država članica iz zajedničkoga europskog fonda. Povećavanje nadležnosti Europske unije u području socijalne politike bez istodobnog povećanja proračuna EU-a u tom području ne bi bilo učinkovito jer visoke socijalne standarde ne bi bilo moguće ostvariti bez dodatnih ulaganja. 


\section{LITERATURA}

Alcidi, C. i Gros, D. (2019). EU Mobile Workers: A challenge to public finances? Contribution for informal ECOFIN. Bucharest: CEPS.

Atoyan, R., Christiansen, L., Dizioli, A., Ebeke, C., Ilahi, N., Ilyina, A., Mehrez, G., Qu, H., Raei, F., Rhee, A. i Zakharova, D. (2016). Emigration and Its Economic Impact on Eastern Europe. Washington: Međunarodni monetarni fond (IMF Staff Discussion Notes 16/7).

Bahar, D., Özgüzel, C, Hauptmann, A. i Rapoport, H. (2019). Migration and Post-Conflict Reconstruction: The Effect of Returning Refugees on Export Performance in the Former Yugoslavia. Bonn: Institute of Labour Economics (IZA) (IZA Discussion Papers 12412).

Beblavý M. i Lenaerts K. (2017). CEPS, Feasibility and Added Value of a European Unemployment Benefit Scheme: Main findings from a comprehensive research project, https://www.ceps.eu/ceps-publications/feasibility-and-added-value-europeanuneriage-benefits-scheme/ (20. 7. 2019.).

Brkljača, I. (2017). Hrvatska na dnu Europe: Doprinos korištenja EU fondova gospodarskom rastu do sada je bio gotovo ravan nuli, Jutarnji list, 15. prosinca, 2017., https://www.jutarnji.hr/biznis/financije-i-trzista/hrvatska-na-dnu-europe-doprinos-koristenja-eu-fondova-gospodarskom-rastu-do-sada-je-bio-gotovo-ravannuli/6847263/ (3. 12. 2019.).

Cavallini, S., Soldi, R., Di Matteo, L., Utma, M. i Errico, B. (2018). Addressing Brain Drain: The Local and Regional Dimension, Commission for Social Policy, Education, Employment, Research and Culture (SEDEC), The European Committee of the Regions, https://cor.europa.eu/en/engage/studies/Documents/addressing-brain-drain/ addressing-brain-drain.pdf (3. 12. 2019.).

Chaffin, J. (2017). Young Poles leave UK to return home as economy booms, Financial Times, 27. listopada, 2017., https://www.ft.com/content/2329a046-ba6f-11e7-8c12$5661783 \mathrm{e} 5589$ (20. 7. 2019.).

D'Adamo, G., Hesse, N., Hartley, J. i Bîea, N. (2019). Wage Dynamics in Romania. Europska komisija (European Economy: Economic Brief 044).

Deutsche Bundesbank (2018). Wage growth in Germany: assessment and determinants of recent developments, Monthly Report, April: 13-27.

Draženović, I., Kunovac, M. i Pripužić, D. (2018). Dynamics and determinants of emigration: the case of Croatia and the experience of new EU member states, Public Sector Economics, 42 (4): 415-447, doi: https://doi.org/10.3326/pse.42.4.3

Europska banka za obnovu i razvoj (2018). Transition Report 2018-19: Work in Transition. London.

Europska komisija (2018a). Prijedlog Uredbe o zaštiti proračuna Unije u slučaju općih nedostataka koji se tiču vladavine zakona u državama članicama, COM/2018/324 final, 2018/0136 (COD), 2. svibnja 2018.

Europska komisija (2018b). EU budget: Commission proposes a modern budget for a Union that protects, empowers and defends, Priopćenje Europske komisije, 2. svibnja 2018., Bruxelles, https://ec.europa.eu/commission/presscorner/detail/en/IP_18_3570 (3. 12. 2018.).

Europska komisija (2018c). The 2018 Ageing Report: Economic and Budgetary Projections for the EU Member States (2016-2070), European Economy: Institutional Paper 079. Bruxelles: Europska komisija. 
Europska komisija (2019). Clarification regarding press reports on President Juncker's comments on European unemployment insurance“" Priopćenje Europske komisije IP/19/141, 5. siječnja 2019., http://europa.eu/rapid/press-release_IP-19-141_en.htm (20. 7. 2019.).

Eurostat (2019). EU citizens living in another Member State - statistical overview, Statistics Explained, https://ec.europa.eu/eurostat/statistics-explained/index.php?title=EU_citizens_living_in_another_Member_State_-_statistical_overview (20.7. 2019.).

Garben, S. Kilpatrick C. i Muir, E. (2017). Towards a European Pillar of Social Rights: upgrading the EU social acquis. Bruges: College of Europe (College of Europe Policy Brief N1/2017).

Goldner Lang, I. (2018a). The EU Financial and Migration Crises: Two Crises - Many Facets of Solidarity. Solidarity, u: A. Biondi, E. Dagilyte i E. Küçük (ur.). EU Law: Legal Principle in the Making. Cheltenham: Edward Elgar Publishing, 133-160.

Goldner Lang, I. (2018b). The European Union and Migration: An Interplay of National, Regional and International Law, American Journal of International Law (AJIL) Unbound, 111: 509-513.

Goldner Lang, I. (2019). The Rule of Law, the Force of Law and the Power of Money in the EU, Croatian Yearbook of European Law and Policy, 15 [u pripremi].

Hungary gives tax breaks to boost population, stop immigration, Deutsche Welle, 10. veljače, 2019., https://www.dw.com/hr/hungary-gives-tax-breaks-to-boost-population-stop-immigration/a-47449980-0 (20. 7. 2019.).

Juncker, J-C. (2015). State of the Union 2015, 9 September 2015, https://ec.europa.eu/ commission/sites/beta-political/files/state_of_the_union_2015_en.pdf (3. 12. 2019.).

Jurić, T. (2017). Suvremeno iseljavanje Hrvata u Njemačku: karakteristike i motivi, Migracijske i etničke teme, 33 (3): 337-371, doi: https://doi.org/10.11567/met.33.3.4

Kingsley, P. (2019). Orban Encourages Mothers in Hungary to Have 4 or More Babies, The New York Times, 11. veljače 2019., https:/www.nytimes.com/2019/02/11/world/ europe/orban-hungary-babies-mothers-population-immigration.html (20. 7. 2019.).

Knijn, T. (2019). Clarification regarding press reports on President Juncker's comments on European unemployment insurance, EuVisions, 6. veljače 2019., http://www. euitions.eu/esu-rethink-justice-solidibility-knijn/ (20. 7. 2019.).

Miličić, K. (2019). Croatia plans to scrap foreign worker quotas amid labour shortage, The Voice of Croatia, HRT, 19. svibnja 2019., https://glashrvatske.hrt.hr/en/news/ economy/croatia-plans-to-scrap-foreign-worker-quotas-amid-labor-shortage (3. 12. 2019.).

Ministarstvo regionalnog razvoja i fondova EU (2019). Fondovi EU - Rezultati u 2018. godini, https://razvoj.gov.hr/UserDocsImages/Istaknute\%20teme/MRRFEU\%20rezultati\%202018.pdf (3. 12. 2019.).

Promocija Plus (2018). Novi hrvatski iseljenici: Privremeni rad ili trajno iseljenje?, Hrvatska udruga poslodavaca, lipanj 2018, https://www.hup.hr/EasyEdit/UserFiles/ Ivana\%20Zlatari\%C4\%87/hupnovi-iseljenici-istrazivanje.pptx (3. 12. 2019.).

Rasnača, Z. (2019). Who is in charge of the European Pillar of Social Rights?, Green European Journal, 29. ožujka 2019., https://www.greeneuropeanjournal.eu/who-is-incharge-of-the-european-Weather-of-social-rights/ (3. 12. 2019.).

Rice-Oxley, M. i Rankin, J. (2019). Europe's south and east worry more about emigration than immigration - poll, The Guardian, 1. travnja 2019., https://www.theguardian. 
com/world/2019/apr/01/europe-south-and-east-worry-more-about-emigrationthan-immigration-poll (20. 7. 2019.).

Rios, B. (2018). Commission sheds some light on cohesion policy reform, Euractiv, 22. lipnja 2018., https://www.euractiv.com/section/economy-jobs/news/commissionsheds-some-light-on-cosions-policy-reform/ (20. 6. 2019).

Romanian Minister suggests EU Work Permits, BBC News, 28. studenog 2018., https:// www.bbc.com/news/world-europe-46371207 (20. 7. 2019.).

Sabato, S., Ghailani, D., PeñaCasas, R., Spasova, S., Corti, F. i Vanhercke, B. (2018). Implementing the European Pillar of Social Rights: what is needed to guarantee a positive social impact. Bruxelles: European Economic and Social Committee.

Strzałkowski, P. (2019). Poland seeks to protect its Ukrainian connection, Euractiv, 22. veljače 2019., https://www.euractiv.com/section/europe-s-east/news/poland-seeksto-protect-its-ukrainian-connection (20. 7. 2019.).

Teodorovici, E (2019). Priopćenje za javnost s neformalnog Ecofina u Bukureštu 6. travnja 2019., https://www.consilium.europa.eu/media/39010/190406-informalecofin-press-release.pdf?utm_source=DSMS\&utm_medium=email\&utm_ campaign=Informal+Ecofin+2\&utm_term=952.56706.30826.0.56706\&utm_pressm_ pressm_pressm_centralni_tres (3. 12. 2019.).

Triollet, R., Mccafferty, E., Alvarez Martinez, A., Bellan, E., Kennedy, P. i Al Khudhairy, D. (2018). JRC Annual Report 2018, Luxembourg: Publications Office of the European Union, doi: https://doi.org/10.2760/197350

Vanhercke, B., Sabato S. i Ghailani D. (2018). Conclusiond: The European Pillar of Social Rights as a game changer, u: B. Vanhercke, D. Ghailani i S. Sabato (ur.). Social Policy in the European Union: State of Play. Bruxelles: ETUI - OSE, 153-172.

Von der Leyen, U. (2019a). A Union that Strives for More: My Agenda for Europe, Political guidelines for the next European Commission 2019-2024, https://ec.europa. eu/commission/sites/beta-political/files/political-guidelines-next-commission_ en.pdf (20. 7. 2019.).

Von der Leyen, U. (2019b). Opening Statement in the European Parliament Plenary Session by Ursula von der Leyen, Candidate for President of the European Commission, Strasbourg, 16. srpnja 2019., https://ec.europa.eu/commission/presscorner/detail/en/ speech_19_4230 (3. 12. 2019.).

Walker, S. (2019). A whole generation has gone: Ukrainians seek a better life in Poland, The Guardian, 18. travnja 2019., https://www.theguardian.com/world/2019/apr/18/ whole-generation-has-gone-ukrainian-seek-better-life-poland-elect-president (3. 12. 2019.).

Zalan, E. (2019). Macron: 14 EU states agree on a migration 'mechanism'. EUobserver, 23. srpnja 2019., https://euobserver.com/political/145514 (3. 12. 2019.).

Zerka, P. (2019). Europe's emigration paradox. European Council on Foreign Relations, 9. srpnja 2019., https://www.ecfr.eu/article/commentary_europes_emigration_paradox (3. 12. 2019.). 


\title{
The Dark Side of Free Movement: When Individual and Social Interests Clash ${ }^{33}$
}

\author{
Iris Goldner Lang, Maroje Lang
}

SUMMARY

Free movement rights have been some of the most positive achievements of EU integration. However, this paper points to the contradictory effects of these rights, especially in Central and Eastern European countries, including Croatia. Free movement of workers creates numerous benefits for the emigrating population and for the EU as a whole as it enables free circulation of labour from places with high unemployment to places where there is a need for labour. However, the social, economic and political downsides for the sending Member States should not be underestimated. This paper aims to explore what has been done so far and which new EU-level measures need to be introduced to mitigate the negative effects of free movement, without restricting it. The text argues that free movement is an important and positive achievement of EU integration, whose downsides should not be utilised or politicised to argue in favour of limiting free movement rights. On the contrary, the answer is not to restrict free movement rights, but to reflect on further EU integration that would aim to reduce regional disparities in the Union by facilitating the development of EU regions that are lagging behind. The chapter is structured in four sections. Following the introductory section, the second section concentrates on recent trends, and on the triggers and effects of intra-EU mobility. The third section explores what initiatives, studies and measures have been employed so far - both at the EU and national levels - to diminish the negative effects of free movement. The concluding section explains why a combination of national and EU measures would be optimal to respond to the downsides of free movement of labour. This section also puts forward various policy proposals that could be employed in the future, such as the reconceptualisation of Union citizenship and the full implementation of the European Pillar of Social Rights, and/or the introduction of new EU-level financial measures that could mitigate the negative effects of free movement, without restricting it.

KEY WORDS: free movement of workers, negative effects, EU funds, EU citizenship, European Pillar of Social Rights

33 This article is a translation of an original article "The Dark Side of Free Movement: When Individual and Social Interests Clash" written in English by Iris Goldner Lang and Maroje Lang. It will be published by Brill in 2020 in a book EU Citizenship and Free Movement: Taking Supranational Citizenship Seriously (edited by S. Mantu, P. Minderhoud and E. Guild). The publisher (Brill) and the editors of the book granted the permission for the article to be translated and published in Croatian. 